\title{
Brevetoxin exposure in sea turtles in south Texas (USA) during Karenia brevis red tide
}

\author{
Jennifer Shelby Walker ${ }^{1}$, Donna J. Shaver ${ }^{1, *}$, Brian A. Stacy ${ }^{2}$, Leanne J. Flewelling ${ }^{3}$, \\ Margaret H. Broadwater ${ }^{4}$, Zhihong Wang ${ }^{5}$
}

${ }^{1}$ National Park Service, Padre Island National Seashore, Division of Sea Turtle Science and Recovery, PO Box 181300, Corpus Christi, TX 78480, USA

${ }^{2}$ NOAA, University of Florida (duty station), 471 Mowry Road, Building 471, Gainesville, FL 32611, USA

${ }^{3}$ Florida Fish and Wildlife Conservation Commission, Fish and Wildlife Research Institute, 100 8th Avenue SE, St. Petersburg, FL 33701, USA

${ }^{4}$ NOAA, National Ocean Service, National Centers for Coastal Ocean Science, Stressor Detection and Impacts Division, 219 Fort Johnson Road, Charleston, SC 29412, USA

${ }^{5}$ JHT, Inc., under contract to NOAA, National Ocean Service, National Centers for Coastal Ocean Science, Stressor Detection and Impacts Division, 219 Fort Johnson Road, Charleston, SC 29412, USA

\begin{abstract}
Five green (Chelonia mydas) and 11 Kemp's ridley (Lepidochelys kempii) sea turtles found dead, or that died soon after stranding, on the southern Texas (USA) coast during 2 Karenia brevis blooms (October 2015, September-October 2016) were tested for exposure to brevetoxins (PbTx). Tissues (liver, kidney) and digesta (stomach and intestinal contents) were analyzed by ELISA. Three green turtles found alive during the 2015 event and 2 Kemp's ridley turtles found alive during the 2016 event exhibited signs of PbTx exposure, including lethargy and/or convulsions of the head and neck. PbTx were detected in 1 or more tissues or digesta in all 16 stranded turtles. Detected PbTx concentrations ranged from 2 to $>2000 \mathrm{ng} \mathrm{g}^{-1}$. Necropsy examination and results of PbTx analysis indicated that 10 of the Kemp's ridleys and 2 of the green turtles died from brevetoxicosis via ingestion. This is the first documentation of sea turtle mortality in Texas attributed to brevetoxicosis.
\end{abstract}

KEY WORDS: Harmful algal bloom $\cdot \mathrm{HAB} \cdot$ Chelonian $\cdot$ Kemp's ridley sea turtle $\cdot$ Lepidochelys kempii $\cdot$ Green sea turtle $\cdot$ Chelonia mydas

\section{INTRODUCTION}

Green (Chelonia mydas) and Kemp's ridley (Lepidochelys kempii) sea turtles are listed as 'threatened' and 'endangered,' respectively, under the US Endangered Species Act (16 U.S.C § 1531 et seq.); thus, investigations of mortalities are important for species management. Both species are found in Texas coastal waters. The most common harmful algal blooms in the Gulf of Mexico are of the marine dinoflagellate Karenia brevis (previously Gymnodinium breve and Ptychodiscus brevis) and can cause red tides in Texas

*Corresponding author: donna_shaver@nps.gov coastal waters (Snider 1987). K. brevis produces a suite of neurotoxins called brevetoxins ( $\mathrm{PbTx}$ ), which can be harmful or fatal to aquatic animals (Landsberg et al. 2009). Red tides, which were documented as early as 1935 (Snider 1987), have caused large fish kills in coastal Texas waters. More recently, multiple classes of harmful algal toxins, including PbTx, were detected in bottlenose dolphins Tursiops truncatus that stranded in Texas in 2008 (Fire et al. 2011). K. brevis blooms have been associated with increases in sea turtle strandings in Florida (Fauquier et al. 2013, A. Foley pers. comm.), but not in Texas.

Outside the USA (C) US Government 2018. Open Access under Creative Commons by Attribution Licence. Use, distribution and reproduction are unrestricted. Authors and original publication must be credited.

Publisher: Inter-Research · www.int-res.com 
Two $K$. brevis blooms occurred in coastal south Texas in recent years, one during October 2015 and another in September and October 2016. Live and dead stranded sea turtles were found during both events, including live turtles with clinical signs associated with brevetoxicosis (Fauquier et al. 2013).

\section{MATERIALS AND METHODS}

\section{Detection of stranded sea turtles and Karenia brevis blooms}

Sea turtles found stranded (dead or alive, washed ashore or floating) or incidentally captured (i.e. entrapped in intake canals of power plants or captured during fishing or sampling activities) in Texas were collected by participants in the Sea Turtle Stranding and Salvage Network (STSSN; Teas 1993). Turtles were located in response to information provided by the public or personnel from other organizations or during systematic surveys conducted by STSSN participants. Sea turtles were categorized as 'offshore' (recovered from beaches or waters of the Gulf of Mexico) or 'inshore' (from beaches or waters of passes and bays) (Fig. 1). Each turtle was documented on a standardized STSSN form that included identification of species, notation of any external abnormalities, and measurements including straight carapace length (SCL: nuchal notch to posterior tip). Live turtles were transported to regional rehabilitation facilities for evaluation and treatment. Carcasses were collected and held at $-4^{\circ} \mathrm{C}$ prior to necropsy. In all, 5 green (4 in 2015 and 1 in 2016) and 11 Kemp's ridley sea turtles (2016) were sampled for PbTx analysis (Table 1). Green turtles were collected between 17 October 2016 and 19 September 2016, and 1 on 30 September 2016, from 2 offshore areas (Gulf of Mexico Beach on North and South Padre Islands) and 2 inshore areas (1 from Aransas Bay and 2 near Port Aransas). Kemp's ridley sea turtles were collected between 14 September and 6 October 2016 from 3 offshore areas (Gulf of Mexico Beach on North and South Padre Islands and on Boca Chica Beach) and 1 was located inshore in the Lower Laguna Madre.

$K$. brevis blooms were identified based on initial detection in seawater by the Imaging FlowCytobot (McLane Research Laboratories) in Port Aransas, Texas, and bloom updates were provided on the Texas Parks and Wildlife red tide website (http:// tpwd.texas.gov/landwater/water/environconcerns/ hab/redtide/). Turtles were selected for this study if they were confirmed by the person collecting the animal to be in an area with active red tide.

\section{Sample collection and laboratory analysis}

Carcasses were thawed and necropsied using procedures outlined by Work (2000), including sex determination by visual examination of gonads. Samples of ca. $100 \mathrm{~g}$ were collected in sample bags, held at $-4^{\circ} \mathrm{C}$, and shipped on dry ice for PbTx analysis to the National Centers for Coastal Ocean Science, National Ocean Service, NOAA (NCCOS; Charleston, SC) for samples collected in 2015 and to the Florida Fish and Wildlife Conservation Commission, Fish and Wildlife Research Institute (FWRI; St. Petersburg, FL) for samples collected in 2016. Different laboratories were used to more rapidly complete analyses during these mortality investigations. Urgency was deemed necessary to determine if mitigation could prevent additional deaths.

For samples analyzed at FWRI, subsamples (2 g) were extracted for PbTx using $80 \%$ methanol as

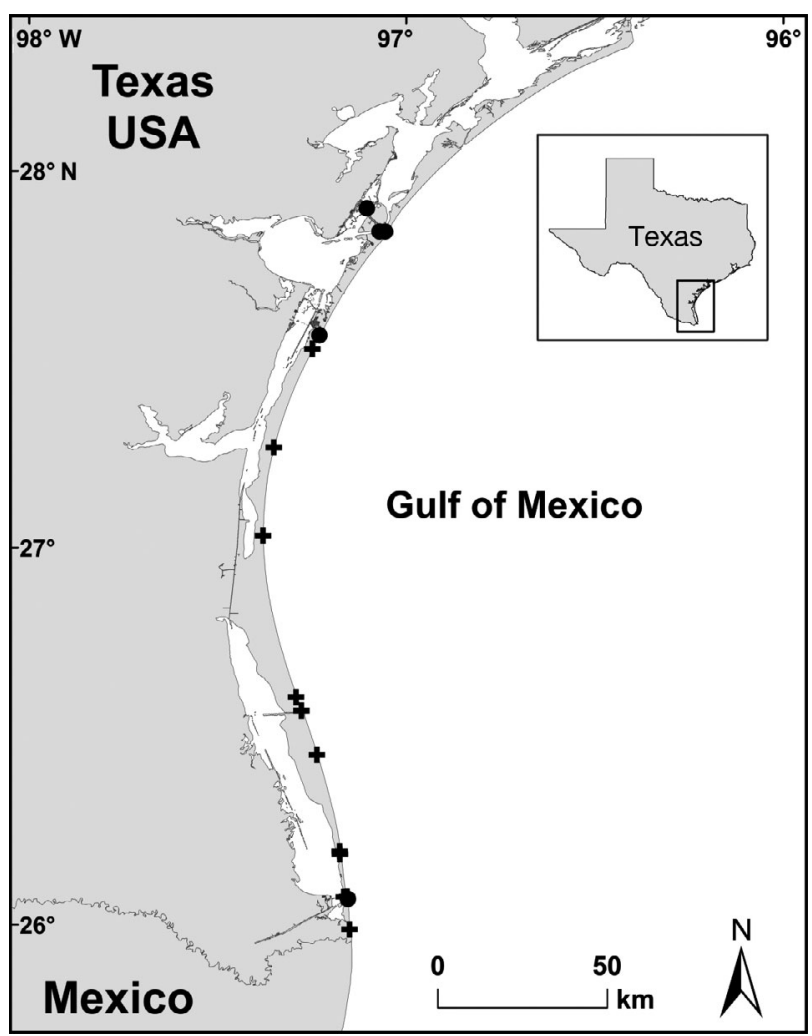

Fig. 1. Stranding locations of green (Chelonia mydas; Kemp's ridley (Lepidochelys kempii; +) sea turtles in Texas, USA 
Table 1. Date, sex, and general location for green (Chelonia mydas) and Kemp's ridley sea turtles (Lepidochelys kempii) stranded in south Texas during Karenia brevis red tide blooms. M: male; F: female; U: undetermined sex; O: Offshore location; I: Inshore location

\begin{tabular}{|c|c|c|c|}
\hline $\begin{array}{l}\text { Stranding } \\
\text { date }\end{array}$ & $\begin{array}{l}\text { Sample } \\
\text { ID }\end{array}$ & Sex & General location \\
\hline \multicolumn{4}{|l|}{ C. mydas } \\
\hline 17 Oct 2015 & $\mathrm{~A} 1^{\mathrm{a}}$ & M & Port Aransas (I) \\
\hline 17 Oct 2015 & B1 & $\mathrm{M}$ & South Padre Island (O) \\
\hline 18 Oct 2015 & $\mathrm{~A} 2^{\mathrm{a}}$ & $\mathrm{U}$ & Port Aransas (I) \\
\hline 19 Oct 2015 & $\mathrm{~T} 1$ & M & Aransas Bay (I) \\
\hline 30 Sep 2016 & L2 & M & North Padre Island $(\mathrm{O})$ \\
\hline \multicolumn{4}{|l|}{ L. kempii } \\
\hline 14 Sep 2016 & $\mathrm{~B} 2^{\mathrm{a}}$ & $\mathrm{F}$ & Lower Laguna Madre (I) \\
\hline 14 Sep 2016 & $\mathrm{~J} 1^{\mathrm{a}}$ & $\mathrm{U}$ & South Padre Island $(\mathrm{O})$ \\
\hline 14 Sep 2016 & $\mathrm{~J} 2^{\mathrm{a}}$ & $\mathrm{U}$ & South Padre Island (O) \\
\hline 15 Sep 2016 & $\mathrm{M}^{\mathrm{a}}$ & $\mathrm{F}$ & North Padre Island (O) \\
\hline 18 Sep 2016 & $\mathrm{~B}^{\mathrm{a}}$ & $\mathrm{F}$ & South Padre Island $(\mathrm{O})$ \\
\hline 28 Sep 2016 & $\mathrm{~T} 2^{\mathrm{a}}$ & $\mathrm{F}$ & North Padre Island (O) \\
\hline 29 Sep 2016 & $\mathrm{~K} 1^{\mathrm{a}}$ & $\mathrm{M}$ & North Padre Island (O) \\
\hline 30 Sep 2016 & $\mathrm{~K} 2^{\mathrm{a}}$ & $\mathrm{M}$ & North Padre Island (O) \\
\hline 3 Oct 2016 & D1 & $\mathrm{F}$ & North Padre Island (O) \\
\hline 6 Oct 2016 & $\mathrm{H} 1^{\mathrm{a}}$ & $\mathrm{M}$ & Boca Chica Beach (O) \\
\hline 6 Oct 2016 & $\mathrm{~L}^{\mathrm{a}}$ & $\mathrm{M}$ & South Padre Island (O) \\
\hline
\end{tabular}

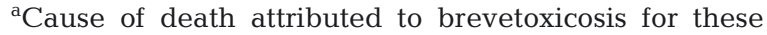
individuals.

described by Flewelling (2008). Extracts were diluted (1:20) and analyzed using an indirect competitive enzyme-linked immunosorbent assay (ELISA; MARBIONC) for PbTx (Naar et al. 2002) with modifications described by Flewelling (2008).

For samples analyzed at NCCOS, subsamples (ca. $2 \mathrm{~g}$ ) were homogenized and extracted 3 times in 3 volumes of acetone, filtered $(0.45 \mu \mathrm{m}$, Pall Acrodisc GxF/GHP syringe filter), evaporated, resuspended in $80 \%$ aqueous methanol $(6 \mathrm{ml})$, and twice solvent partitioned with hexane $(3 \mathrm{ml})$, and then the methanolic fraction was collected, evaporated, and resuspended in 100\% methanol (1-2 ml, 1:1 sample:solvent). Extracts were stored at $-20^{\circ} \mathrm{C}$ until analysis. Extracted samples were diluted $(1: 20)$ and analyzed using a direct competitive ELISA for PbTx, following methods outlined by Maucher et al. (2007). Both ELISAs utilize cross-reactivity of PbTx to anti-PbTx antibodies. Quantitation is determined via competition between PbTx in the sample and PbTx conjugated to a signal enzyme for binding to anti-PbTx antibodies and compared with a curve prepared from dihydrobrevetoxin-B (PbTx-3). The limit of detection was 2-10 ng PbTx-3 equivalents $\mathrm{g}^{-1}$ or $\mathrm{ml}^{-1}$ sample. Results are reported as PbTx ng g ${ }^{-1}$ for brevity.

ELISA-positive samples were cleaned on C18 solid phase extraction (SPE) cartridges (500 mg Agilent
Bond Elut sorbent in a $10 \mathrm{ml}$ tube) and analyzed by liquid chromatography/mass spectrometry (LC/MS) for parent PbTx and their derivatives. Sample extracts equivalent to $0.5 \mathrm{~g}$ of tissue were loaded on pre-conditioned SPE cartridges in $25 \%$ methanol; $^{\circ}$ sample tubes were then washed with $6 \mathrm{ml} 25 \%$ methanol, and the wash solution of each sample was transferred to the SPE cartridge. PbTx were eluted with $8 \mathrm{ml}$ methanol. The SPE eluates were dried and re-dissolved in methanol (1 $\mathrm{g}$ tissue equivalent in $1 \mathrm{ml}$ of methanol) for analysis. Liquid chromatographic separations were performed on a Luna C8(2) column $(150 \times 2 \mathrm{~mm}, 5 \mu \mathrm{m}$; Phenomenex $)$ using an Agilent Technologies Model 1100 LC system. Mobile phase consisted of water and acetonitrile with $0.1 \%$ formic acid additive using a gradient elution. The flow rate was $0.2 \mathrm{ml} \mathrm{min}^{-1}$. The eluent from LC was analyzed by a Sciex 4000 QTRAP hybrid triple quadrupole/linear ion trap mass spectrometer equipped with a TurboV ${ }^{\mathrm{TM}}$ interface. The analysis of PbTx congeners and metabolites by mass spectrometry was achieved by multiple reaction monitoring.

$\mathrm{PbTx}$ congeners monitored included brevetoxin$\mathrm{B}(\mathrm{A})$, dihydrobrevetoxin-B(A), tetrahydrobrevetoxin$\mathrm{B}$, hydrolysis products of brevetoxin-B(A) and dihydrobrevetoxin-B(A), and cysteine conjugates of brevetoxin-A(B) and their sulfoxides. Detection limits were $0.3,1.7$, and $1.2 \mathrm{ng} \mathrm{ml}^{-1}$ for dihydrobrevetoxinB, S-desoxybrevetoxin-B2, and brevetoxin-B2, respectively, for toxin standards in methanol. Retention times of other toxin congeners were determined by injecting sample extracts containing these congeners as confirmed previously by enhanced product ion spectra. PbTx congeners were confirmed present by LC/MS in 21 of 31 ELISA-positive samples.

Univariate ANOVA was used to compare concentrations of PbTx in tissues (liver and kidney tissues) and digestive fluids (intestinal contents and stomach contents) between species. We excluded 1 sample of intestinal contents (green turtle; B1) that exceeded detection limits and 1 kidney tissue sample (Kemp's ridley; K1) that was below the threshold of detection (see Table 2). All analyses were performed using SPSS 14.0 for Windows (IBM SPSS Statistics).

\section{Permitting and animal welfare}

This study was carried out in strict accordance with the Guide for the Care and Use of Laboratory Animals of the National Institutes of Health. Work by National Park Service personnel was authorized under USFWS Permit TE840727-3, TPWD Scientific 
Permit SPR-0190-122, and NPS Institutional Animal Care Protocols NPS IACUC for 2011-15 and 2016-18.

\section{RESULTS}

All 16 turtles sampled in this study were found dead or died within $2 \mathrm{~d}$ of being located. Three of the green sea turtles were found alive during the 2015 red tide event and exhibited signs similar to those seen in other sea turtles exposed to PbTx from red tide exposure (e.g. neurologic signs, lethargy, muscle weakness; Fauquier et al. 2013). All were lethargic when located and died within $2 \mathrm{~d}$. Two Kemp's ridley turtles found alive during the 2016 event exhibited signs of PbTx exposure. One large (58.5 cm SCL) female Kemp's ridley was discovered on 15 September 2016 on Padre Island National Seashore Gulf Beach with convulsions of the head and neck and died soon after discovery. Another adult female Kemp's ridley, which was found live on South Padre Island Gulf Beach on 16 September 2016 and was not sampled, was lethargic, floating, and exhibited similar convulsions. This turtle was successfully rehabilitated by Sea Turtle, Inc. and was released on 14 October 2016.

PbTx was detected in all sample types from all individuals with the exception of a kidney from 1 Kemp's ridley which was below the threshold of detection. Detected toxin concentration ranged from $2 \mathrm{ng} \mathrm{g}^{-1}$ to

Table 2. Summary of brevetoxin (PbTx) concentrations in tissues and digesta of green (Chelonia mydas) and Kemp's ridley (Lepidochelys kempii) sea turtles stranded in south Texas, as measured by ELISA

\begin{tabular}{|c|c|c|c|}
\hline \multirow{2}{*}{ Sample type } & \multicolumn{2}{|c|}{$\operatorname{PbTx}\left(\mathrm{ng} \mathrm{g}^{-1}\right)$} & \multirow[t]{2}{*}{$\mathrm{N}$} \\
\hline & Mean $\pm \mathrm{SD}$ & Range & \\
\hline \multicolumn{4}{|l|}{ C. mydas } \\
\hline Kidney & $12.8 \pm 12.9$ & $2-34$ & 5 \\
\hline Liver & $24.4 \pm 28.9$ & $6-75$ & 5 \\
\hline Stomach contents & $41.4 \pm 58.5$ & $6-145$ & 5 \\
\hline Intestinal contents & $56.7 \pm 41.6^{\mathrm{a}}$ & $7-100^{a}$ & 3 \\
\hline \multicolumn{4}{|l|}{ L. kempii } \\
\hline Kidney & $105.0 \pm 53.7^{b}$ & $67-143^{\mathrm{b}}$ & 2 \\
\hline Liver & $215.1 \pm 132.8$ & $25-372$ & 7 \\
\hline Stomach contents & $360.3 \pm 597.7$ & $9-1687$ & 7 \\
\hline Intestinal contents & $169.9 \pm 212.2$ & $8-672$ & 8 \\
\hline \multicolumn{4}{|c|}{ 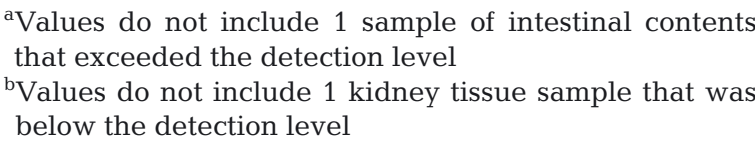 } \\
\hline
\end{tabular}

$>2000$ PbTx-eq $\mathrm{ng} \mathrm{g}^{-1}$ for samples collected from green turtles (Table 2). Green turtles sampled $(\mathrm{n}=5)$ were juveniles ranging from 29.0-39.1 cm SCL; 4 of the 5 were identified as male based on gonad morphology.

Concentrations ranged from below detection limits (<LD) to $1687 \mathrm{PbTx} \mathrm{ng} \mathrm{g}^{-1}$ for samples collected from 11 Kemp's ridley turtles that stranded during the 2016 red tide (Table 2). Kemp's ridleys sampled $(\mathrm{n}=$ 11) were adults ( $\geq 60.0 \mathrm{~cm}$ SCL) or large sub-adults and ranged from $52.6-61.5 \mathrm{~cm}$ SCL with a sex ratio of 5F:4M. Post-mortem scavenging of 1 green turtle and scavenging and decomposition of 2 Kemp's ridleys prevented sex determination. Due to lack of information on the stability of PbTx in decomposing tissues and the fact that decomposition and scavenging could have caused cross contamination of PbTx, concentrations should be considered qualitative.

Green turtles sampled had significantly lower PbTx in kidney $(p=0.009)$ and liver tissue $(p=0.011)$ than Kemp's ridleys (Table 2). There was no significant difference between species in stomach content $\operatorname{PbTx}(\mathrm{p}=0.268)$ and intestinal content $\operatorname{PbTx}(\mathrm{p}=$ 0.397) (Table 2).

The majority of turtles necropsied had intact carcasses, and no significant injuries or illness were found. Due to good body condition in these turtles and the lack of apparent alternative causes of death, the cause of death was attributed to brevetoxicosis (Fauquier et al. 2013). Results were inconclusive regarding the probable cause of death for $1 \mathrm{Kemp}$ 's ridley, due to fishing line entanglement, and 3 green turtles, due to scavenging, signs of water inhalation, and 1 which had excessive epibiota present, a possible indication of long-term illness, and an embedded hook in its left front flipper with signs of infection.

\section{DISCUSSION}

We document here the first mortality of sea turtles in Texas attributed to brevetoxicosis. It is unknown whether turtles died previously of brevetoxicosis and went undetected, or whether this is an emerging threat that has manifested as the green and Kemp's ridley turtle populations have increased in Texas (Shaver 1998, Shaver et al. 2016, 2017). Previous red tide events in south Texas were not associated with notable increases in sea turtle strandings, nor were neurological signs noted in live turtles. The frequency of occurrence and severity of Gulf of Mexico Karenia brevis red tides may be increasing (Brand \& Compton 2007). However, K. brevis blooms in Texas 
are sporadic and less frequent than those occurring in Florida (Thyng et al. 2013).

Green turtles had significantly lower tissue (kidney and liver) concentrations of PbTx than Kemp's ridleys. This was also documented in Florida green and Kemp's ridleys (A. Foley pers. comm.). The cause of this difference is not known. Considerations include habitat or diet-dependent differences in toxin exposure. Juvenile green turtles are mostly herbivorous and inhabit primarily inshore waters, whereas adult and near-adult Kemp's ridleys are benthic carnivores that frequent nearshore Gulf waters (Shaver 1991).

Flewelling et al. (2005) found that turtle grass Thalassia testudinum, a common food choice for green turtles in coastal Texas (Howell et al. 2016), accumulated and stored $\mathrm{PbTx}$, resulting in manatee deaths after the bloom subsided. One green turtle was determined to have extremely elevated PbTx concentration (>2000 $\mathrm{ng} \mathrm{ml}^{-1}$ ) in its enteric contents. Though this turtle stranded dead on the Gulf beach, it was immediately adjacent to the Brazos Santiago Pass on the South Padre Island beach and may have been foraging inshore before it succumbed to brevetoxicosis; its stomach was full of sea grasses and algae, indicating recent active feeding. The role of red tide in the cause of death of the 3 green turtles with lower concentrations of PbTx was unclear. All 3 of these turtles had concurrent injuries, signs of chronic illness, or assessment was limited due to scavenging. The remaining 2 green turtles, including the one with the highest concentrations noted above, were intact, had no signs of injury or illness, and appeared otherwise healthy, indicating that the cause of death was most likely brevetoxicosis. It is also important to note that these PbTx concentrations are from single points in time and provide no information on accumulation and depuration of PbTx from tissues. In a recent study by Cocilova et al. (2017), $\mathrm{PbTx}-3$ was cleared within days from the tissues of freshwater turtles experimentally exposed to sublethal doses, while longer elimination times (several weeks) have been observed in naturally exposed sea turtles (Fauquier et al. 2013).

Kemp's ridleys sampled were found offshore, with 1 exception, and had higher concentrations of brevetoxins in tissues than green turtles. Concentrations for most were higher than seen in Kemp's ridleys found actively swimming and feeding during a K. brevis bloom in Florida (Perrault et al. 2014, 2017; $>1.00-33.8 \mathrm{ng} \mathrm{ml}^{-1}$ measured in blood plasma). Brevetoxicosis was determined to be the cause of death for 10 of these turtles due to detection of PbTx in tissues and digesta and the finding of no significant injuries or signs of illness during necropsy. The remaining turtle (DHT01) had fishing line entangled around its neck and esophageal injury, making the cause of death ambiguous. There may have been additional alternative undetected causes for mortality, such as forced submergence due to fisheries interactions, although no evidence of this was found. Since the deaths of multiple adult and near-adult Kemp's ridleys were linked to brevetoxicosis during this event, $K$. brevis blooms could impact recovery of this highly endangered species if severity and/or frequency of blooms increase in the future.

Based on our findings, we recommend enhanced searches for stranded sea turtles during future red tide events in south Texas to locate and document affected animals and provide broader sampling for toxin detection. This increased effort will better inform our understanding of red tides and their contribution to sea turtles mortality in the region. Moreover, timely intervention by stranding responders, and diagnosis and treatment of live individuals with brevetoxicosis is critical for successful recovery and release (Fauquier et al. 2013). Additionally, improvements in the current red tide monitoring system in Texas, including more sampling locations and standardized frequent sampling, would improve wildlife management responses as well as protect public health and recreation concerns associated with harmful algal blooms.

Acknowledgements. Amos Rehabilitation Keep (ARK), Sea Turtle, Inc., Texas Parks and Wildlife Department, and the University of Texas Rio Grande Valley Coastal Studies Laboratory helped locate and collect stranded turtles included in this study in conjunction with the STSSN. Cynthia Rubio created the map. In 2016, samples were prepared for analysis by Bennie Haynes. This publication does not constitute an endorsement of any commercial product or intend to be an opinion beyond scientific or other results obtained by the National Oceanic and Atmospheric Administration (NOAA). No reference shall be made to NOAA, or this publication furnished by NOAA, to any advertising or sales promotion which would indicate or imply that NOAA recommends or endorses any proprietary product mentioned herein, or which has as its purpose an interest to cause the advertised product to be used or purchased because of this publication.

\section{LITERATURE CITED}

Brand LE, Compton A (2007) Long-term increase in Karenia brevis abundance along the Southwest Florida Coast. Harmful Algae 6:232-252

* Cocilova CC, Flewelling LJ, Bossart GD, Granholm AA, Milton SL (2017) Tissue uptake, distribution and excretion of brevetoxin-3 after oral and intratracheal exposure in the freshwater turtle Trachemys scripta and the diamondback terrapin Malaclemys terrapin. Aquat Toxicol 187: 29-37 
Fauquier DA, Flewelling LJ, Maucher J, Manire CA and others (2013) Brevetoxin in blood, biological fluids, and tissues of sea turtles naturally exposed to Karenia brevis blooms in central west Florida. J Zoo Wildl Med 44: 364-375

Fire SE, Wang Z, Byrd M, Whitehead HR (2011) Co-occurrence of multiple classes of harmful algal toxins in bottlenose dolphins (Tursiops truncatus) stranding during an unusual mortality event in Texas, USA. Harmful Algae 10:330-336

Flewelling LJ (2008) Vectors of brevetoxins to marine mammals. PhD dissertation, University of South Florida, Tampa, FL

Flewelling LJ, Naar JP, Abbott JP, Baden DG and others (2005) Brevetoxicosis: red tides and marine mammal mortalities. Nature 435:755-756

* Howell LN, Reich KJ, Shaver DJ, Landry AM Jr, Gorga CC (2016) Ontogenetic shifts in diet and habitat of juvenile green sea turtles in the northwestern Gulf of Mexico. Mar Ecol Prog Ser 559:217-229

Landsberg JH, Flewelling LJ, Naar J (2009) Karenia brevis red tides, brevetoxins in the food web, and impacts on natural resources: decadal advancements. Harmful Algae 8:598-607

Maucher JM, Briggs L, Podmore C, Ramsdell JS (2007) Optimization of blood collection card method/enzyme linked immunoassay for monitoring exposure of bottlenose dolphin to brevetoxin-producing red tides. Environ Sci Technol 41:563-567

Naar J, Bourdelais A, Tomas C, Kubanek J and others (2002) A competitive ELISA to detect brevetoxins from Karenia brevis (formerly Gymnodinium breve) in seawater, shellfish and mammalian body fluid. Environ Health Perspect 110:179-185

Perrault JR, Schmid JR, Walsh CJ, Yordy JE, Tucker AD (2014) Brevetoxin exposure, superoxide dismutase activity and plasma protein electrophoretic profiles in wildcaught Kemp's ridley sea turtles (Lepidochelys kempii) in southwest Florida. Harmful Algae 37:194-202

Editorial responsibility: Thierry Work, Honolulu, Hawaii, USA
Perrault JR, Stacy NI, Lehner AF, Mott CR and others (2017) Potential effects of brevetoxins and toxic elements on various health variables in Kemp's ridley (Lepidochelys kempii) and green (Chelonia mydas) sea turtles after a red tide bloom event. Sci Total Environ 605-606:967-979

* Shaver DJ (1991) Feeding ecology of Kemp's ridley in south Texas waters. J Herpetol 25:327-334

Shaver DJ (1998) Sea turtle strandings along the Texas coast, 1980-94. In: Zimmerman R (ed) Characteristics and causes of Texas marine strandings. Tech Rep NMFS 143. NOAA, US Department of Commerce, Miami, FL, p 57-72

Shaver DJ, Rubio C, Walker JS, George J and others (2016) Kemp's ridley sea turtle (Lepidochelys kempii) nesting on the Texas coast: geographic, temporal, and demographic trends through 2014. Gulf Mex Sci 33: 158-178

Shaver DJ, Tissot PE, Streich MM, Walker JS and others (2017) Hypothermic stunning of green sea turtles in a western Gulf of Mexico foraging habitat. PLOS ONE 12: e0173920

Snider R (ed) (1987) Red tide in Texas: an explanation of the phenomenon. TAMU-SG-87-502. Marine Information Service, Texas A\&M Sea Grant College Program, College Station, TX

Teas WG (1993) Species composition and size class distribution of marine turtle strandings on the Gulf of Mexico and southeast United States coast, 1985-1991. Tech Memo NMFS-SEFSC-315. NOAA, US Department of Commerce, Miami, FL

* Thyng KM, Hetland RD, Ogle MT, Zhang X, Chen F, Campbell L (2013) Origins of Karenia brevis harmful algal blooms along the Texas coast. Limnol Oceanogr Fluids Environ 3:269-278

Work TM (2000) Sea turtle necropsy manual for biologists in remote refuges: USGS, Honolulu, HI. https://www.nwhc. usgs.gov/hfs/Globals/Products/turtleml.pdf (accessed 2 October 2017)

Submitted: July 10, 2017; Accepted: November 14, 2017 Proofs received from author(s): January 16, 2018 